\title{
Development of a non-functional pancreatic neuroendocrine tumor and a duodenal ulceration after cholecystoduodenostomy in a cat
}

\author{
Ontwikkeling van een niet-functionele neuro-endocriene pancreastumor \\ en een duodenale ulcus na cholecystoduodenostomie bij een kat
}

${ }^{1}$ E. Bianchini, ${ }^{2}$ N. Devriendt, ${ }^{3}$ H. De Cock, ${ }^{2}$ F. Mortier, ${ }^{1}$ T. Rick, ${ }^{2}$ D. Paepe, ${ }^{2} H$. de Rooster

${ }^{1}$ Department of Veterinary Medical Imaging and Small Animal Orthopedics, Faculty of Veterinary Medicine, Ghent University, Salisburylaan 133, 9820 Merelbeke, Belgium

${ }^{2}$ Small Animal Department, Faculty of Veterinary Medicine, Ghent University, Salisburylaan 133, 9820 Merelbeke, Belgium

${ }^{3}$ Medvet - Veterinary Pathology Services, Emiel Vloorsstraat 9, 2020 Antwerpen, Belgium

erika.bianchini@ugent.be

\begin{abstract}
A
BSTRACT

A six-year-old Ragdoll with previous extrahepatic biliary tract obstruction due to cholangiohepatitis, treated with cholecystoduodenostomy, was presented for acute vomiting, hyporexia, and weight loss. Abdominal ultrasound examination revealed randomly distributed hepatic nodules and dilated biliary ducts. Gastroduodenoscopy showed a patent cholecystoduodenostoma but disclosed a perforated duodenal ulceration. Conversion to celiotomy revealed extensive liver pathology, a discrete pancreatic nodule, and a duodenal ulcer opposite to the cholecystoduodenostoma. The cat was euthanized intra-operatively and necropsy was performed. The intrahepatic biliary tract of the right liver lobes was obstructed and severely dilated, whereas bile from the left lobes drained through the cholecystoduodenostoma. Histopathologic diagnoses were a primary pancreatic tumor, positive for glucagon on immunohistochemistry, with liver metastases, chronic purulent cholecystitis, and duodenal ulceration. To the authors' knowledge, this is the first report in which the development of pancreatic neoplasia is described in a cat with a history of biliary tract disease.
\end{abstract}

\section{SAMENVATTING}

Een zes jaar oude ragdoll met een voorgeschiedenis van cholecystoduodenostomie na extrahepatische galgangobstructie door chronische cholangiohepatitis werd aangeboden omwille van acuut braken, verminderde eetlust en gewichtsverlies. Op het abdominale echografisch onderzoek werden diffuus verspreide levernodules gezien en gedilateerde galgangen. Via gastroduodenoscopie werd een patente cholecystoduodenostomie opening gezien maar eveneens een geperforeerde duodenale ulcus. Tijdens de daaropvolgende exploratieve celiotomie werden uitgesproken afwijkingen ter hoogte van de lever vastgesteld en het darmulcer in de wand van het duodenum tegenover de cholecystoduodenostomieopening werd bevestigd. Daarenboven werd een kleine nodule ter hoogte van de pancreas opgemerkt. In overleg met de eigenaar werd de kat intraoperatief geëuthanaseerd waarna een necropsie werd uitgevoerd. De afvoer van de sterk gedilateerde intrahepatische galgangen van de rechterleverlobben was geblokkeerd. De gal afkomstig van de linkerleverlobben draineerde in het duodenum via de cholecystoduodenostomie-opening. De histologische diagnose was een primaire pancreastumor, die aankleurde voor glucagon op immunohistochemie, met levermetastases. Er was ook sprake van chronisch purulente cholecystitis en een duodenale ulcus. Volgens de auteurs is dit de eerste casuïstiek waarin de ontwikkeling van een neoplastisch proces wordt beschreven ter hoogte van de pancreas bij een kat met een voorgeschiedenis van galgangproblemen. 


\section{INTRODUCTION}

Cholecystoduodenostomy is widely considered to be the best surgical procedure for biliary diversion in dogs and cats in case of obstruction or trauma affecting the extrahepatic biliary tree, when the gallbladder is not affected by the disease process (Doran and Moore, 2007; Morrison et al., 2008). Reports on longterm complications in cats are scarce and comprise stenosis of the stoma, reflux cholangiohepatitis, recurrent cholelithiasis, chronic weight loss, and duodenal ulceration, the last being observed after cholecystojejunostomy (Eich and Ludwig, 2002; Mayhew et al., 2002; Bacon and White, 2003; Buote et al., 2006; Doran and Moore, 2007). In cats, the close anatomical relationship between the pancreatic and biliary duct predisposes to concurrent pathologies (Mayhew et al., 2002; Jergens, 2012); however, it is often unclear which problem is causal, a consequence, or even coincidental. In human medicine, bile acids are suspected to play a role in the carcinogenesis of pancreatic tumors (Feng and Chen, 2016), but a similar association has not yet been described in cats. Moreover, the reported incidence of feline primary pancretic neoplasia is extremely low and pancreatic neuroendocrine carcinomas are even more rare (Seaman, 2004; Linderman et al., 2013). In the present case, the development of a pancreatic neoplasia and a duodenal ulceration are reported after previous cholecystoduodenostomy. To the authors' knowledge, this has not been reported previously in the veterinary literature.

\section{CASE DESCRIPTION}

A six-year-old, female Ragdoll was presented for acute vomiting, hyporexia and weight loss. Nine months earlier, cholecystoduodenostomy had been performed because of common bile duct obstruction; chronic suppurative cholangiohepatitis with dilation and proliferation of bile ducts and mild ulcerative, neutrophilic and plasma-cellular enteritis had been diagnosed and treated with long-term antimicrobial therapy. Although after recovery, the cat had been free of clinical signs till a few days before being presented again, she had experienced significant weight loss over time.

At presentation, a palpable mass in the cranial abdomen was detected. General blood analysis, including coagulation profile, did not show significant abnormalities. Abdominal ultrasound (US) revealed multiple ovoid, hyperechoic, well-defined nodules of various sizes (1-2 cm), randomly distributed over the entire hepatic parenchyma. The intrahepatic biliary ducts were moderately to severely dilated and contained partially echoic bile and focal hyperechoic areas (gas). The gallbladder was positioned over the duodenum and demonstrated a moderate amount of echoic bile in its lumen. The exact attachment and opening towards the duodenum were not clearly vi- sualized due to gas content of the duodenum in this region; however, the opening appeared to be permeable for a few millimeters. No significant ultrasonographic abnormalities were observed in the remaining abdominal organs. Ultrasound-guided fine-needle aspirates of the liver nodules revealed several clusters of epithelial cells with augmented nucleus/cytoplasm ratio, mild to moderate anisocytosis and anisokaryosis. The bile, aspirated under US guidance, was nonpigmented and viscous, and contained fibrin-like debris. These characteristics belong to the definition of "white bile", a finding associated with biliary tract obstruction (Hashmonai et al., 1984). Microscopically, a large number of moderately degenerated neutrophils with numerous intra- and extracellular rod-shaped bacteria was present. Microbiological testing of the collected bile revealed the presence of Escherichia coli, sensitive to potentiated amoxicillin.

The main differential diagnosis was recurrent cholangiohepatitis and biliary tract (sub)obstruction with either reactive changes of the intrahepatic biliary tract epithelium (due to chronic bacterial infection) or with concurrent epithelial neoplasia. Treatment was initiated with amoxicillin-clavulanic acid $\left(\mathrm{Kesium}^{\circledR}\right.$, Ceva, Bruxelles, Belgium), ursodeoxycholic acid (Ursochol, Zambon, Bruxelles, Belgium), metoclopramide (Emeprid ${ }^{\mathbb{Q}}$, Ceva, Libourne, France), mirtazapine (Mirtazapine, Mylan, Bruxelles, Belgium) and tramadol (Tralieve, Dechra Veterinary Products NV, Lille, Belgium). Liver biopsies were advised to investigate possible neoplasia.

At the control visit twenty days later, hyporexia, occasional vomiting and weight loss were still present. On US, the bile was increased in echogenicity compared to the previous examination, and focal spots of gas were present in the region of the cholecystoduodenostoma. The gallbladder showed a moderate amount of echoic bile in its gravity dependent portion of the lumen. The stoma was difficult to visualize but appeared permeable. Because of the presence of white bile at the previous examination and the inability to see the stoma of the cholangioduodenostomy well with US, it was decided to perform gastroduodenoscopy. The endoscopic examination confirmed patency of the cholecystoduodenostoma but revealed ectasia at the duodenal wall opposite to the cholecystoduodenostomy site. In the center of this dilation, smooth white-colored tissue was surrounded by hyperemic edges, indicative for a duodenal ulcer. Because of the development of pneumoperitoneum with a sudden decrease in respiratory rate and saturation, the procedure was converted to ventral midline celiotomy. The right liver lobes were completely replaced by a multinodular mass composed of $0.5 \mathrm{~cm}$ up till 2 $\mathrm{cm}$ slightly umbilicated nodules, grey to yellow and firm with a necrotic center on the cut surface. The left liver lobes presented similar nodules, in less number. The omentum was adherent to the liver surface at several sites, to the gallbladder, and to the proximal duodenum. A discrete, irregular and hard nodule of $1 \mathrm{~cm}$ 
was palpable in the right lobe of the pancreas. Due to the extensive liver pathology, the cat was euthanized intra-operatively.

At necropsy, once the omentum was released, a small perforation was seen in the mesenteric side of the duodenal wall, opposite to the cholecystoduodenostoma at the level of the duodenal ulcer (Figure 1). The cholecystoduodenostoma drained normal greenish bile, originating from the left liver lobes. The right bile ducts were obstructed and contained viscous white material. Samples of left and right liver lobes, duodenum and pancreas were taken for histopathological examination. The most important histologic findings were present in the liver lobes and pancreas. Within the pancreas, there was a poorly circumscribed infiltrative neoplastic mass composed of noduli of densely packed nests with moderately pleomorphic oval cells with oval nucleus with coarsely granulated chromatin and a moderate amount of well-defined eosinophilic cytoplasm. The neoplastic nests were surrounded by a small amount of collagen stroma. Mitoses were numerous, MC:34 (2.37 $\left.\mathrm{mm}^{2}\right)$.

Histologic examination of the right liver lobes revealed a diffuse infiltrative, widely disseminated neoplastic process composed of moderately circumscribed nodules with densely packed irregular tubular structures lined by a moderately pleiomorphic cuboidal epithelium, with a round to oval nucleus with coarsely granulated chromatin and a small amount of well-defined eosinophilic cytoplasm. The neoplastic tubules were surrounded by a small amount of collagen stroma. Mitoses were moderate; MC: $14\left(2.37 \mathrm{~mm}^{2}\right)$. In the remaining liver parenchyma, the bile ducts were surrounded by a concentric band of slightly mucinous collagen stroma with a mild to moderate infiltrate of neutrophils, macrophages and lymphocytes. Similar neoplastic nodules were present randomly distributed in the left liver lobes.

The neoplastic cells in the pancreas and liver resulted positive for chromogranin A (Chrom A 1/1000, Abcam, Cambridge, UK), pancytokeratin (CK Pan CK AE1/AE3, Dako, Glostrup, Denmark) and glucagon (Glucagon ab10988 Clone K79bB10, Abcam, Cambridge, UK), and negative for cytokeratin 7 (Cytokeratin 7, Dako, Glostrup, Denmark), insulin (Insulin RTU antibody, code IK002, Dako, Glostrup, Denmark) and gastrin (Gastrin GA519, Dako, Glostrup, Denmark). Based on these immunohistochemical characteristics in combination with the distribution of neoplastic nodules, the diagnosis of primary pancreatic neuroendocrine carcinoma, immunoreactive for glucagon, was made (Figure 2).

\section{DISCUSSION}

In this case report, a case of pancreatic neuroendocrine carcinoma with massive liver metastases and duodenal ulceration is described in a cat that had undergone a cholecystoduodenostomy nine months earlier.

The reported incidence of feline primary pancreatic neoplasia is extremely low and reports on pancreatic neuroendocrine neoplasia (pan-NEN), other than insulinomas, are even more rare, although the true incidence of pan-NEN might be higher than assumed (Seaman, 2004; Linderman et al., 2013). In general, pan-NENs are divided into two groups: functional (hormone-producing and -secreting) and nonfunctional neoplasms (Uribe Galeano et al., 2017).
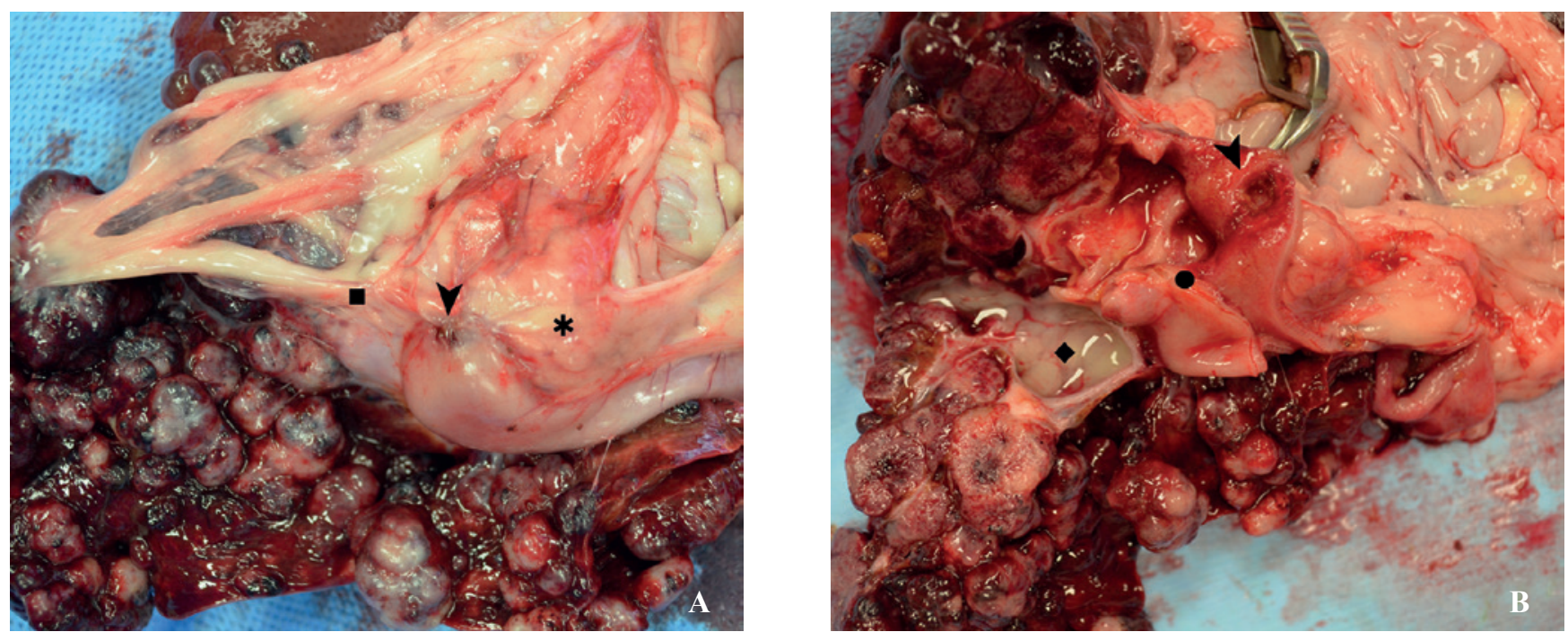

Figure 1. Post-mortem images of the cat ten months after cholecystoduodenostomy. A. The omentum was fixed to a liver metastasis and to the site of the duodenal ulcer $(>)$, opposite to the site where the gall bladder ( $\square)$ was attached to the duodenal wall. A discrete nodule on the pancreas ( $\star$ ) betrayed the underlying primary pancreatic neoplasia. $B$. After incising the liver parenchyma and the duodenum, patency of the cholecystoduodenostomy site $(\bullet)$ was confirmed. At the opposite site, the duodenal wall was ulcerated ( $>$ ). The severely dilated intrahepatic biliary tract of the right liver lobes contained white, viscous bile $(\diamond)$. 

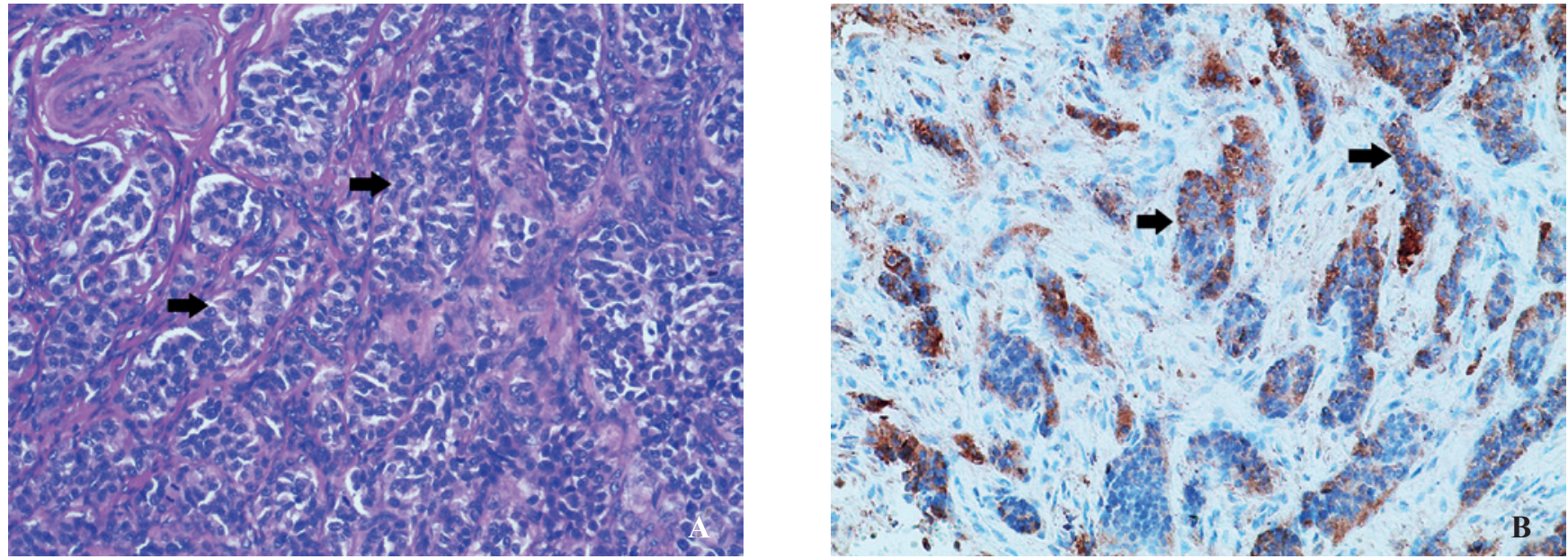

Figure 2. Histologic images of the pancreatic neuroendocrine neoplasia. A. Neuroendocrine tumor nests in the pancreas (arrow); H\&E, (400x). B. Immunohistochemical glucagon-positive staining of the nests in the pancreas (arrow); IHC staining for glucagon, $(200 x)$.

As in humans (Halfdanarson et al., 2008), most are non-functional, eventually producing hormones, but without inducing clinically evident hormone-related syndromes (Seaman, 2004; Linderman et al., 2013). As a consequence, pan-NENs are generally incidental findings, unless they cause clinical signs due to a mass effect (Cloyd, 2015).

In the cat reported here, the pan-NEN stained negative for insulin and gastrin on immunohistochemistry but positive for glucagon. Glucagon-producing tumors are rarely reported in dogs and cats (Rosol and Meuten, 2017). In cats, one pan-NEN with exocrine differentiation (Michishita et al., 2017), one glucagonoma in a cat with necrolytic migratory erythema (Sahinduran and Ozmen, 2017), one glucagon-positive gastrin-secreting pancreatic tumor (Middleton and Watson, 1983), and one glucagon-producing hepatic neuroendocrine carcinoma (Asakawa et al., 2013) have been reported. In the present case, primary pancreatic neoplasia was not suspected clinically, related to the small and most likely non-functional pancreatic nodule, nor was it diagnosed by US, presumably because the small lesion was masked by the massive liver pathology and the previous cholecystoduodenostomy. Furthermore, the difference between acute pancreatitis and pancreatic neoplasia is difficult to detect by US (Bennett et al., 2001). In the past, any tumor staining positive for glucagon on immunohistochemistry was called glucagonoma, but, according to recent WHO guidelines on tumors of the digestive system, tumors in the absence of typical clinical syndromes should nowadays be termed non-functional NENs (Nagtegaal et al., 2020).

Only during necropsy, it became clear that the white bile obtained via US-guidance was not collected from the gallbladder itself (as this drained normal green bile coming from the left liver lobes), but from a part of the dilated right extrahepatic biliary tracts. This error prompted to proceed with further investi- gation, which otherwise would possibly have been postponed.

Liver metastases are frequent findings in human pancreatic glucagonomas (Soga and Yakuwa, 1998), either with or without diabetico-dermatogenic syndrome (DDS and metastases were also present in two of the reported feline pancreatic endocrine tumors) (Middleton and Watson, 1983; Michishita et al., 2017). In human medicine, metastatic rate seems to correlate with the size of the primary tumor and its malignancy (Soga and Yakuwa, 1998). In the cat of this present case, the liver masses stained positive for glucagon during immunohistochemistry, confirming the diagnosis of a primary pancreatic neoplasia. However, macroscopically, the dimension and severity of the liver lesions compared to the pancreatic nodule rather suggested a primary liver neoplasia.

Based on the absence of typical clinical symptoms, it can be assumed that this feline pan-NEN was nonfunctional. A test for blood glucagon is not readily available for cats. Serum biochemistry did not reveal indirect signs of hyperglucagonemia (e.g. hyperglycemia, anemia, hypoaminoacidemia). Necrolytic migratory erythema, a syndrome associated in humans (Tierney and Badger, 2004), dogs (Gross et al., 1993), and two cats with glucagonoma (Asakawa et al., 2013; Sahinduran and Ozmen, 2017) was not observed.

It might not have been a coincidence that the pancreatic tumor in this cat was observed after biliary tract disease. The strong anatomical connection between pancreas and gall bladder, especially in the feline species, predisposes to mutual pathologic influences, but a clear physiological basis has not yet been established (Jergens, 2012). Since the feline extrahepatic biliary anatomy closely resembles the human situation (Mayhew et al., 2002), abnormal bile acid flow combined with severe bacterial cholangiohepatitis could have promoted neoplastic changes in the pancreas similar to what has been described in hu- 
mans (Cigrovski Berkovic et al., 2014). It has been suggested that bile acids systemically activate cancer-signalling pathways, but also locally induce pancreatic carcinogenesis, although typically, pancreatic adenocarcinoma would be expected rather than neuroendocrine neoplasia (Feng and Chen, 2016). At the time of the previous surgery, the pancreas had appeared normal and liver biopsies had tested negative for malignant disease, but had revealed chronic suppurative cholangiohepatitis, which could also have triggered carcinogenesis. In humans, chronic inflammation and pro-inflammatory cytokines have been shown to be modifying factors in tumor growth $(\mathrm{Ci}-$ grovski Berkovic et al., 2014).

An additional finding in the cat of the present case was the ulcer opposite the cholecystoduodenostomy site. Duodenal ulcer formation is a known complication after cholecystojejunostomy (Doran and Moore, 2007; Mehler, 2011). When bile is diverted from the duodenum to the jejunum via a rerouting procedure, gastric acid secretion by the stomach is increased while there is no longer bile for neutralization of gastric acids in the duodenum, leading to ulcerative damage to the proximal duodenum (Davies et al., 1985). Cholecystoduodenostomy theoretically does preserve the neuroendocrine reflex of acid inhibition and is therefore preferred (Mehler, 2011).

The question why a duodenal ulcer was formed in this case and, in particular, whether its localization was incidental, is difficult to answer. Firstly, it can be hypothesized that the amount of bile reaching the duodenum was insufficient to neutralize the gastric acids (Mehler, 2011), since bile of the right liver lobes was no longer drained. It could be argued whether the constant "dripping" of bile onto the contralateral duodenal wall, due to the absence of a sphincter regulating the bile flow, may have resulted in a mechanical damage with disruption of the normal architecture. Lastly, duodenal ulcers have been related to a specific type of pan-NEN, gastrinoma, and its associated Zollinger-Ellison syndrome; this type of tumor has previously been reported in a cat with duodenal ulcers (Middleton and Watson, 1983). In the present case, immunohistochemistry of the tumor tested negative for gastrin. Nevertheless, it is known that pan-NENs can stain positive for several pancreatic hormones, with predominance of one hormone. Furthermore, correlation between immunohistochemistry and bioactivity is not always apparent (Rosol and Meuten, 2017). Therefore, a role of gastrin in the pathogenesis of the duodenal ulcer cannot completely be excluded in the present case.

In conclusion, abnormal bile acid flow combined with severe bacterial cholangiohepatitis could have promoted the development of the pancreatic neoplasia, similar to bile acid involvement suggested in the carcinogenesis of human pancreatic cancer. Formation of the duodenal ulcer opposite to the cholecystoduodenostoma might have been caused by insufficient neuroendocrine acid inhibition and/or by irritation due to constant contact with bile. Based on both findings, pancreatic neoplasia and duodenal ulceration opposite to the cholecystoduodenostoma should be considered in the differential diagnosis of cats that clinically deteriorate after prior recovery of biliary tract surgery.

\section{REFERENCES}

Asakawa M.G., Cullen J.M., Linder K.E. (2013). Necrolytic migratory erythema associated with a glucagonproducing primary hepatic neuroendocrine carcinoma in a cat. Veterinary Dermatology 24 (4), 466-e110.

Bennett P., Hahn K., Toal R., Legendre A. (2001). Ultrasonographic and cytopathological diagnosis of exocrine pancreatic carcinoma in the dog and cat. Journal of the American Animal Hospital Association 37 (5), 466-473.

Cigrovski Berkovic M., Cacev T., Catela Ivkovic T., ZjacicRotkvic V., Kapitanovic S. (2014).New insights into the role of chronic inflammation and cytokines in the etiopathogenesis of gastroenteropancreatic neuroendocrine tumors. Neuroendocrinology 99 (2), 75-84.

Cloyd J.M. (2015). Non-functional neuroendocrine tumors of the pancreas: Advances in diagnosis and management. World Journal of Gastroenterology 21 (32), 9512.

Davies AH., Wheeler M.H., Psaila J., Rhodes J., Newcombe R.G., Jones J.M., Biol L.I., Procter D., Adrian T.E., Bloom S.R. (1985). Bile exclusion from the duodenum: Its effect on gastric and pancreatic function in the dog. Digestive Diseases and Sciences 30 (10), 954-960.

Doran I., Moore A.H. (2007). Biliary tract surgery in the dog and cat: Indications and techniques. Companion Animal 12 (1). 24-30.

Feng H.-Y., Chen Y.-C. (2016). Role of bile acids in carcinogenesis of pancreatic cancer: An old topic with new perspective. World Journal of Gastroenterology 22 (33), 7463-7477.

Gross T.L., Song M.D., Havel P.J., Ihrke P.J. (1993). Superficial necrolytic dermatitis (necrolytic migratory erythema) in dogs. Veterinary Pathology 30 (1), 75-81.

Halfdanarson T.R., Rabe K.G., Rubin J., Petersen G.M. (2008). Pancreatic neuroendocrine tumors (PNETs): incidence, prognosis and recent trend toward improved survival. Annals of Oncology 19 (10), 1727-1733.

Hashmonai M., Kam I., Schramek A. (1984). The etiology of 'white bile' in the biliary tree. Journal of Surgical Research 37 (6), 479-486.

Jergens A.E. (2012). Feline idiopathic inflammatory bowel disease: what we know and what remains to be unraveled. Journal of Feline Medicine and Surgery 14 (7), 445-458.

Linderman M.J., Brodsky E.M., de Lorimier L.-P., Clifford C.A., Post G.S. (2013). Feline exocrine pancreatic carcinoma: a retrospective study of 34 cases: Feline exocrine pancreatic carcinoma: 34 cases. Veterinary and Comparative Oncology 11 (3), 208-218.

Mayhew P.D., Holt D.E., McLear R.C., Washabau R.J. (2002). Pathogenesis and outcome of extrahepatic biliary obstruction in cats. Journal of Small Animal Practice 43 (6), 247-253.

Mehler S.J. (2011). Complications of the extrahepatic biliary surgery in companion animals", Veterinary Clinics of North America: Small Animal Practice 41 (5), 949-967. 
Michishita M., Takagi M., Kishimoto T.E., Nakahira R., Nogami T., Yoshimura H., Hatakeyama H., Azakami D., Ochiai K.,Takahashi K. (2017). Pancreatic neuroendocrine carcinoma with exocrine differentiation in a young cat. Journal of Veterinary Diagnostic Investigation 29 (3), 325-330.

Middleton D.J., Watson A.D.J. (1983). Duodenal ulceration associated with gastrin-secreting pancreatic tumor in a cat. Journal of the American Veterinary Medical Association 183 (4), 461-462.

Nagtegaal I.D., Odze R.D., Klimstra D., Paradis V., Rugge M., Schirmacher P.,Washington K.M., Carneiro F., Cree I.A.(2020). The 2019 WHO classification of tumours of the digestive system. Histopathology 76, 182-188.

Rosol T.J., Meuten D.J. (2017). Tumors of the endocrine glands. In: Meuten, D.J. (editor). Tumors in Domestic Animals. Fifth edition, John Wiley \& Sons, Inc., Hoboken, NJ, USA, 766-833.

Sahinduran S., Ozmen O. (2017). Necrolytic migratory erythema in a cat with glucagonoma syndrome. Acta Scientiae Veterinariae 45, 1-5.
Seaman R.L. (2004). Exocrine pancreatic neoplasia in the cat: A case series. Journal of the American Animal Hospital Association 40 (3), 238-245.

Soga J., Yakuwa Y. (1998). Glucagonomas/diabetico-dermatogenic syndrome (DDS): A statistical evaluation of 407 reported cases. Journal of Hepato-Biliary-Pancreatic Surgery 5 (3), 312-319.

Tierney E.P., Badger J. (2004). Etiology and pathogenesis of necrolytic migratory erythema: review of the literature. Medscape General Medicine 6 (3), 4.

Uribe Galeano C., Fabregat Prous J., Busquets Barenys J., Pelaez Serra N., Secanella Medayo L., Ramos Rubio E., RuizOsuna S., VillabonaArtero C.(2017). Tumores neuroendocrinos no funcionantes de páncreas incidentales de pequeño tamaño: Resultados de una serie con manejo no quirúrgico. Cirurgía Española 95 (2), 83-88.

\section{Paard eten}

Vanouds, met name in de middeleeuwen, werd het paard geassocieerd met de adel - was zelfs aan de adel voorbehouden - en speelde het een belangrijke rol in de cavalerie. Door deze bijzondere positie was er ook vroeger al duidelijk weerstand tegen het eten van paardenvlees, behalve als het om oude afgeleefde werkpaarden ging. Paarden, zeker deze waarop ridders reden hadden eigennamen en waren wijd en zijd bekende persoonlijkheden. (...). Een paard heeft dan ook geen poten maar 'benen', geen kop, maar een 'hoofd'. Kortom het staat tamelijk dicht bij de mens.

Uit: Lemaire T. (2017). Onder dieren, Ambo/Anthos, Amsterdam, p. 22 